Hydrol. Earth Syst. Sci., 16, 3101-3114, 2012

www.hydrol-earth-syst-sci.net/16/3101/2012/

doi:10.5194/hess-16-3101-2012

(C) Author(s) 2012. CC Attribution 3.0 License.

(c) (i)

\title{
Water resources trends in Middle East and North Africa towards 2050
}

\author{
P. Droogers ${ }^{1}$, W. W. Immerzeel ${ }^{1}$, W. Terink ${ }^{1}$, J. Hoogeveen ${ }^{2}$, M. F. P. Bierkens ${ }^{3}$, L. P. H. van Beek ${ }^{3}$, and B. Debele ${ }^{4}$ \\ ${ }^{1}$ FutureWater, Wageningen, The Netherlands \\ ${ }^{2}$ FAO, Water Development and Management Unit (NRL), Rome, Italy \\ ${ }^{3}$ Utrecht University, Dept. Physical Geography, The Netherlands \\ ${ }^{4}$ World Bank, Middle East and North Africa Region, Washington, D.C., USA
}

Correspondence to: P. Droogers (p.droogers@futurewater.nl)

Received: 20 March 2012 - Published in Hydrol. Earth Syst. Sci. Discuss.: 3 April 2012

Revised: 25 July 2012 - Accepted: 18 August 2012 - Published: 3 September 2012

\begin{abstract}
Changes in water resources availability can be expected as consequences of climate change, population growth, economic development and environmental considerations. A two-stage modeling approach is used to explore the impact of these changes in the Middle East and North Africa (MENA) region. An advanced, physically based, distributed, hydrological model is applied to determine the internal and external renewable water resources for the current situation and under future changes. Subsequently, a water allocation model is used to combine the renewable water resources with sectoral water demands. Results show that total demand in the region will increase to $393 \mathrm{~km}^{3} \mathrm{yr}^{-1}$ in 2050, while total water shortage will grow to $199 \mathrm{~km}^{3} \mathrm{yr}^{-1}$ in 2050 for the average climate change projection, an increase of $157 \mathrm{~km}^{3} \mathrm{yr}^{-1}$. This increase in shortage is the combined impact of an increase in water demand by $50 \%$ with a decrease in water supply by $12 \%$. Uncertainty, based on the output of the nine GCMs applied, reveals that expected water shortage ranges from $85 \mathrm{~km}^{3} \mathrm{yr}^{-1}$ to $283 \mathrm{~km}^{3} \mathrm{yr}^{-1}$ in 2050 . The analysis shows that $22 \%$ of the water shortage can be attributed to climate change and $78 \%$ to changes in socioeconomic factors.
\end{abstract}

\section{Introduction}

Water resources are being altered due to changes in climate, population, economic development and environmental considerations. The Middle East and North Africa (MENA) region can be considered as the most water-scarce region of the world. According to FAO AQUASTAT (WRI, 2005) the average renewable water resources per capita for 2005 are about $47000,20000,11000,4000,6000$ and $1500 \mathrm{~m}^{3}$ per year for South America, North America, Europe, SubSaharan Africa, Asia and the Middle East, and North Africa (MENA) regions, respectively. Moreover, water availability is highly variable within the MENA region. For example, within MENA the per capita water availability is currently less than $200 \mathrm{~m}^{3}$ per year in Yemen and Jordan. The 4th Assessment Report of the IPCC (IPCC, 2007) projects strong changes in climate across the MENA region. Temperatures are expected to increase while at the same time substantial decreases in precipitation are projected. These elevated temperatures will result in higher evapotranspiration demands and this will, in combination with decreases in precipitation, severely stress the water resources in the region. The impact of these changes is assessed by various other studies (e.g. Hanasaki et al., 2008; Elshamy et al., 2009; Wit and Stankiewicz, 2006; Legesse et at., 2003) indicating an increasingly large water deficit in the future.

However, for many of the 22 MENA countries, climate change is not the only challenge that the water sector faces. Population growth and economic development, with associated increases in irrigation, domestic and industrial water requirements, might even be a bigger challenge (Falkenmark and Lannerstad, 2005; Rosegrant et al., 2009). One of the major challenges in the MENA countries is to increase agricultural production to sustain the fast growing population. The "Agriculture towards 2030/2050" study of FAO (FAO, 2006) shows that, on a global scale, agricultural production 
can grow in line with food demand. However in the MENA region the situation differs as high population growth rates are expected and water is a crucial constraint. The FAO study estimates that $58 \%$ of the renewable water resources in the MENA will be used for food production by 2030 and farfetching efficiency measures are required.

The World Bank study "Making the Most of Scarcity: accountability for Better Water Management Results in the Middle East and North Africa" (World Bank, 2007) asks the question of whether countries in MENA can adapt to meet all these combined challenges. The study argues that they have to, because, if not, the social and economic consequences will be enormous. The study continues that the MENA countries are insufficiently equipped to meet the above challenges and adaptation is essential to face the otherwise unavoidable social, economic and budgetary consequences. Still, this study lacks clear numbers and potential options to address these issues across the entire MENA region.

A study by Trieb and Muller-Steinhagen (2008) focusing on the options desalination might offer to overcome water shortages estimated substantial increases in water demand in the MENA region. This study was based on FAO statistics and assumptions on growth rates in population. The projected increase in total water demand is from $270 \mathrm{~km}^{3}$ in 2000 to $460 \mathrm{~km}^{3}$ in 2050 . The study also projected that the demand-supply gap will increase from $50 \mathrm{~km}^{3}$ in 2000 to $150 \mathrm{~km}^{3}$ in 2050 .

However, a complete analysis on water demand and water shortage over the coming $50 \mathrm{yr}$ based on a combined use of hydrological and water resources models, remote sensing and socio-economic changes has never been undertaken for the MENA region. Studies published so far have not been able to reveal the full picture as their focus has been on a limited number of aspects only. Outstanding issues with previous studies include the following: (i) they focus on only climate or agriculture; (ii) they are based on statistics rather than on a full hydrological approach; (iii) they are based on annual or monthly approaches rather than on the required daily approach to capture hydrological processes; (iv) they use only a limited amount of GCM realizations, (v) they model the hydrology with coarse spatial resolution; and (vi) they do not include socio-economic aspects. In this study these issues are addressed by integrating various data sources, different model concepts and an integration of various projections for the future.

The objective of this study is to assess water demand and supply for the 22 MENA countries up to the year 2050 , taking into account changes in climate, population and economic development.

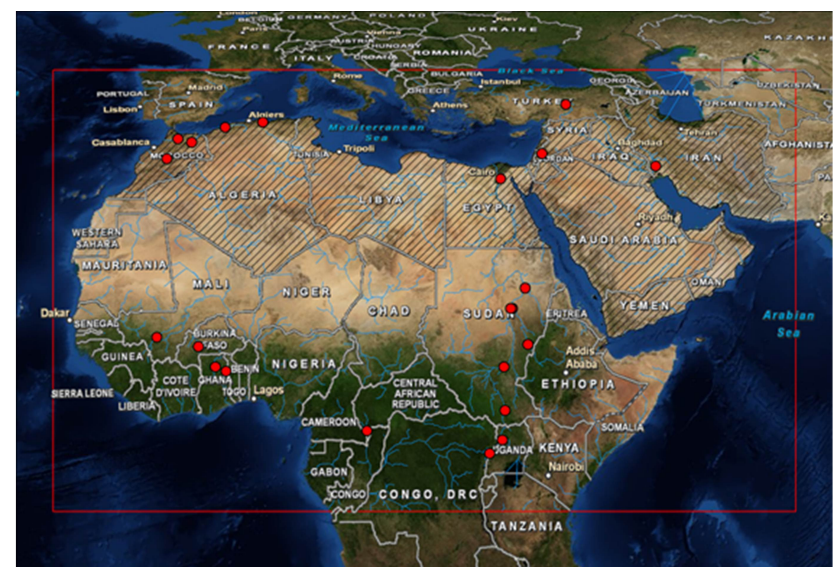

Fig. 1. Spatial domain of the hydrological model (red box). MENA countries are shaded. Red dots show the location of the GRDC stations used for calibration.

\section{Materials and methods}

\subsection{Study area}

The MENA region (Middle East and North Africa) is located between longitudes $13^{\circ} \mathrm{W}$ and $60^{\circ} \mathrm{E}$ and between latitudes $15^{\circ} \mathrm{N}$ and $40^{\circ} \mathrm{N}$ covering a surface area of about 11.1 million square kilometers or about $8 \%$ of the area of the world (Fig. 1). Because of the prevailing arid conditions in the region, about $85 \%$ of the area is desert. The 21 countries $^{1}$ in the MENA region have many similarities, although differences in environments, resources and economies exist. The Maghreb sub-region (North Africa countries) extends from the Mediterranean climate zone to the arid zone. Rainfall occurs in the winter season with a clear and dry summer season. There are differences in the climate within the sub-region between the Maghreb countries. The Maghreb climate shows a drying and warmer gradient from north to south and a divided and dispersed hydrography with some average-sized rivers only in Morocco. Egypt has an arid climate and a simple hydrography with very limited internal resources and only one river, the Nile River, entering the country from Sudan. The sub-region of the GCC (Gulf Cooperation Countries $=$ Middle East) has a complete desert climate that is very hot in the summer and relatively cold in the winter with very scarce rainfall. Finally, the Mashreq region (countries like Iran, Iraq, Lebanon, and Syria) has a milder and wetter climate compared to the GCC countries.

MENA is the home for about 300 million people, or about $5 \%$ of the world's population, with an average annual population growth rate of $1.7 \%$ (World Bank, 2005). About $60 \%$ of the total population lives in urban areas, but this percentage is on the rise as people migrate to urban areas in search for better economic opportunities.

\footnotetext{
${ }^{1}$ In the analysis we consider 22 regions (referred to as countries) given the separated locations of Gaza Strip and West Bank.
} 
MENA is the driest and most water-scarce region in the world, and this is increasingly affecting the economic and social development of most countries of the region. MENA has about $0.7 \%$ of the world's available freshwater resources (CEDARE, 2006; based on FAO-AquaStat). Today, the average per capita water availability in the region is slightly above the physical water scarcity limit at about $1076 \mathrm{~m}^{3} \mathrm{yr}^{-1}$ (compared to the world average of about 8500 ). However, country figures vary significantly from about $2000 \mathrm{~m}^{3} /$ capita/year or more in Iran and Iraq to less than $200 \mathrm{~m}^{3} /$ capita/year in Jordan, the West Bank and Gaza, Yemen and many Gulf countries. The exact percentage of the area that experiences physical water scarcity is unknown as so far data are only available per country. Generally, the Mashreq region is the richest in water resources, whereas the GCC countries are the poorest in the region. Surface water still constitutes a main resource in the region. More than two-thirds of the $360 \mathrm{~km}^{3}$ average total annual renewable water resources in MENA come from surface resources (rainfall, rivers, springs and lakes) according to FAO (2006). Rainfall is highly variable in MENA, both temporally and geographically. Overall, average annual rainfall is less than $100 \mathrm{~mm}$ in $65 \%$ of the region, between 100 and $300 \mathrm{~mm}$ in $15 \%$ of the region and more than $300 \mathrm{~mm}$ in the remaining $20 \%$ of the region (Allam, 2002).

The main permanent rivers in MENA are the Nile in Maghreb and the Tigris and Euphrates in the Mashreq. The GCC region has hardly any rivers of importance. The average annual Nile flow at Aswan is reported to be about $84 \mathrm{~km}^{3} \mathrm{yr}^{-1}$ (CEDARE, 2006), out of which more than $80 \%$ occurs between August and October. Abu-Zeid and ElShibini (1997) reported that this $84 \mathrm{~km}^{3} \mathrm{yr}^{-1}$ is the average natural flow (for the period 1901-1950) and that this number was used in the design of the High Aswan Dam and to establish a treaty between Egypt and Sudan in 1959. This treaty includes allocating $55.5 \mathrm{~km}^{3} \mathrm{yr}^{-1}$ to Egypt and $18.5 \mathrm{~km}^{3} \mathrm{yr}^{-1}$ to Sudan, while the remaining $10 \mathrm{~km}^{3} \mathrm{yr}^{-1}$ are considered to be lost to evaporation from Lake Nasser. However, it should be noticed that there is an ongoing debate about the actual flows at Aswan (Molden, 2007). The Euphrates passes through Syria and then Iraq with average annual flows of 26 and $30 \mathrm{~km}^{3}$ as it enters Syria and Iraq respectively (Abu-Zeid et al., 2004). The Tigris and Euphrates join together in Iraq to form Shatt al-Arab which eventually drains into the Arabian Gulf.

\subsection{Methods}

A two-stage modeling approach is used in this study. First an advanced, physical based, distributed, hydrological model is applied to determine the internal and external renewable water resources for the current situation and under future changes (climate, socio-economics). Second, a water allocation model is used to analyze the linkage between the renewable water resources and the sectoral water demands. The water allocation model includes groundwater, surface water and reservoirs as sources of water that are used to sustain the sectoral water demands. The allocation model links supply and demand for each country, sector and supply sources. The hydrological model runs on a daily time step and a spatial resolution of $10 \mathrm{~km}$, and aggregated monthly time series of surface water and natural groundwater recharge serve as input to the water allocation model.

The two models are set up for a period of $50 \mathrm{yr}$ (20012050), where the period 2001-2010 is based on actual data on climate and water requirements (see hereafter). For the period 2011-2050, projections on climate and water demands were included and the overall water resources availability and demand are assessed.

\subsubsection{Hydrological model}

Current and future water availability are assessed using a revised version of the PCR-GLOBWB (PCRaster Global Water Balance) hydrological model (Van Beek and Bierkens, 2009; Van Beek et al., 2011). PCR-GLOBWB can be described as a physical-based, dynamic and distributed model written in the metalanguage of the PCRaster GIS package (Wesseling et al., 1996). The PCR-GLOBWB concepts are comparable to HBV-model (Bergström, 1995), with the main difference that PCR-GLOBWB is fully distributed and implemented on a regular grid. Within this grid, variations in soil, land cover and topography are taken into account by parameterizing sub-grid variability (Van Beek and Bierkens, 2009). Such a grid-based approach is, over large areas, often preferred over the traditional sub-basin approach (Meigh et al., 1999).

To our knowledge, this is the first time that a hydrological model has been developed capturing the entire MENA region at such high spatial and temporal resolutions. Various modeling approaches for single river basins have been developed successfully (e.g. Conway, 1993; Elshamy, 2008). However, most of these modeling study objectives were to focus on stream flows only. For this study all components of the complete water balance were required including land processes such as evapotranspiration by crops and natural vegetation, groundwater recharge, and runoff. Obviously, model performance should be considered in the context of the application of the modeling results (Moriasi et al., 2007).

Originally, PCR-GLOBWB was set up as a global model with a spatial resolution of $0.5^{\circ}(\sim 50 \mathrm{~km})$. More recently, the model was applied at a higher resolution in Asia with the aim to assess future water availability in large Asian river basins in relation to food security (Immerzeel et al., 2009, 2010). For this study, it has been downscaled to a spatial resolution of $10 \mathrm{~km}$, with inclusion of the sub-grid variability in vegetation cover. This resolution is the optimum tradeoff between required detail for hydrological processes, data availability and calculation times (Wada et al., 2011; Sperna Weiland, 2012).

The study focuses on the 21 countries in the MENA (Middle East and North Africa) region. However, to assess the 
availability of water resources in the MENA region, it is necessary to include the upstream river basins of all MENA countries in the model domain. To identify the upstream areas, an overlay was made using a map with major drainage basins derived from the Hydro1K database (USGS, 2012). The model domain extends relatively far to the south to include the entire Nile basin boundary (Fig. 1). The size of the model domain is $8860 \mathrm{~km} \times 5250 \mathrm{~km}$. Details of the hydrological model development can be found elsewhere (Immerzeel et al., 2010, 2012).

\subsubsection{Water assessment model}

The PCR-GLOBWB model is used to determine changes in water resources availability as a result of changes in climate and irrigation demands. The linkage between water resources and water demand requires a different type of model, and here the WEAP modeling framework (SEI, 2005) is used. WEAP is considered to be amongst the best tools to undertake integrated analysis of different scenarios (e.g. Droogers and Perry, 2008).

WEAP (SEI, 2005) operates on the basic principles of a water balance. WEAP represents the system in terms of its various supply sources (e.g. rainfall, rivers, groundwater, and reservoirs); withdrawal, transmission and wastewater treatment facilities; ecosystem requirements, water demands and pollution generation. WEAP is applicable to many scales: municipal and agricultural systems, single catchments or complex transboundary river systems. WEAP calculates a water balance for every node in the system. Water is allocated to meet instream and consumptive requirements, taking into account demand priorities, supply preferences, mass balance and other constraints (Yates et al., 2005).

The conceptual base as built using the WEAP model (referred to as the MENA Water Outlook Framework, in short MENA-WOF) is shown in Fig. 2. It is assumed that within each country the following objects are present: streams, reservoirs, groundwater, irrigation demand, domestic demand and industrial demand. These objects are interconnected with each other, and per country a lumped approach is taken. Details for each of these objects include the following:

- Streams represent all the surface water within a country. The inflow into the surface water originates from the PCR-GLOBWB results. Water can be extracted for domestic, industrial and irrigation needs; water can be stored in the reservoir; and additional outflow to the sea (or any other outlet point of the country) can occur.

- Reservoirs are represented by one single lumped object and present total storage capacity in a specific country. Reservoirs can receive water from the streams, and water can be released to support the demand.

- Groundwater is, similar to the reservoir object, one single lumped object and represents total groundwater storage in a specific country. Groundwater receives water

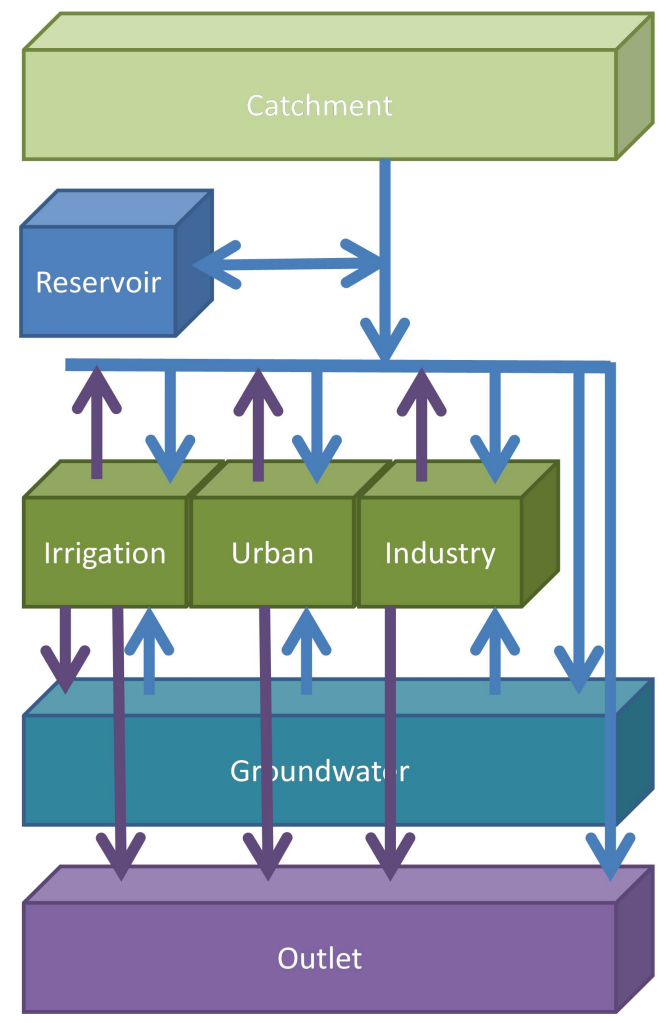

Fig. 2. Conceptual framework of the MENA Water Outlook Framework (MENA-WOF).

from natural recharge as calculated by PCR-GLOBWB and additional return flows from irrigated areas. Water is abstracted from the three demand nodes (irrigation, domestic and industry).

- Irrigation represents all the water requirements for irrigation in a country. Water is obtained from the surface water and the groundwater. Return flows by drainage and surplus irrigation applications can return to the groundwater or to the surface water.

- Domestic represents all water required for domestic supply. Water is obtained from the surface water and the groundwater. Return flows can return upstream in the stream (so can be reused) and/or downstream in the stream (so no reuse).

- Industry represents all water required for industrial supply. Water is obtained from the surface water and the groundwater. Return flows can return upstream in the stream (so can be reused) and/or downstream in the stream (so no reuse). 


\subsection{Data}

\subsubsection{Spatial and temporal resolution}

As discussed by Wada et al. (2011) and Sperna Weiland (2012), selection of model and thus data resolution is the optimum tradeoff between required detail for hydrological processes, data availability and calculation times. Moreover, the objective of the study, e.g. scoping, feasibility, detailed design, etc., should be considered as well. For this particular analysis, the nature of the study is scoping. For the hydrological model PCR-GLOBWB, all data are converted to a 10$\mathrm{km}$ spatial resolution and a daily temporal resolution. Since vegetation is analyzed at sub-grid level, vegetation data were used at $1 \mathrm{~km}$. Data for the water assessment model MENAWOF are aggregated to country level and the temporal resolution to a monthly base. Details of the individual datasets are provided hereafter.

\subsubsection{Digital elevation data}

To determine the distribution of elevation, the HYDRO1K database was used (USGS, 2012). HYDRO1k is a geographic database developed to provide comprehensive and consistent global coverage of topographically derived datasets, including streams, drainage basins and ancillary layers derived from the USGS 30 arcsecond digital elevation model (DEM) of the world (about $1 \times 1 \mathrm{~km}$ ). It is known that the original DEM has inaccuracies in flat areas like the Sudd, and the HYDRO1K dataset provides therefore hydrologically correct DEMs along with ancillary datasets for use in continentaland regional-scale modeling and analyses.

\subsubsection{Vegetation}

PCR-GLOBWB requires information on the fraction of tall and short vegetation for each grid cell, monthly crop factors (required to convert reference evapotranspiration to potential evapotranspiration), monthly fractional vegetation covers and monthly maximum interception storage. This information is derived from the Global Land Cover Characterization (GLCC) database (USGS, 2008). The US Geological Survey (USGS), the University of Nebraska-Lincoln (UNL), and the European Commission's Joint Research Centre (JRC) have generated this 1-km resolution global land cover characteristics database for use in a wide range of environmental research and modeling applications. The data have been subjected to a formal accuracy assessment (USGS, 2008).

\subsubsection{Soils}

Soil physical properties for PCR-GLOBWB are derived from the FAO gridded soil map of the world (FAO, 1998). Data are available at a $1-\mathrm{km}$ spatial resolution. The most prominent features that are required are depth of the soil layers, sat-

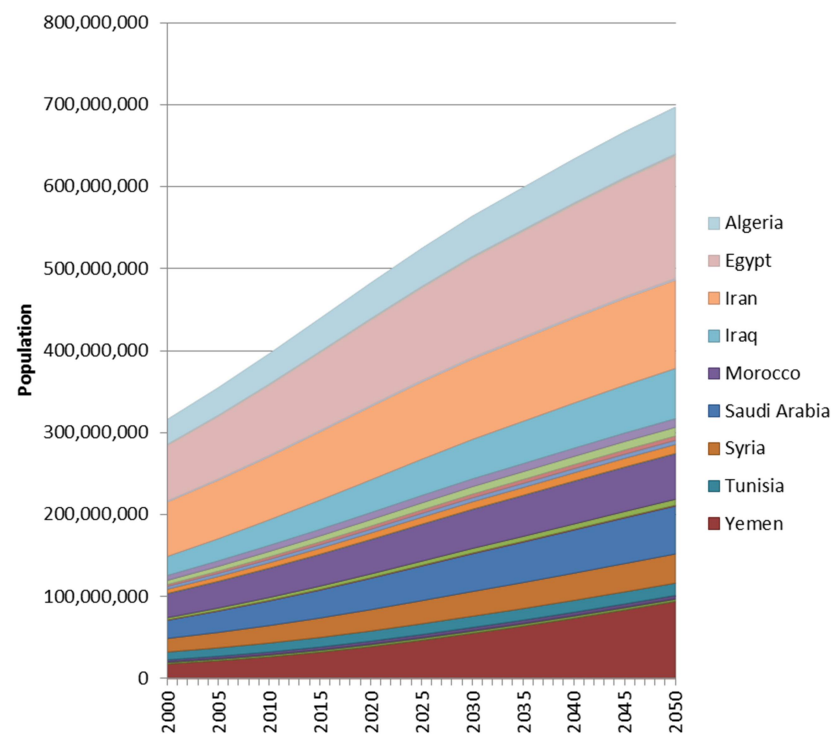

Fig. 3. Projected population in the MENA region for the 22 countries. Only some selected countries are shown in the legend (Source: CIESIN, 2002).

urated and residual volumetric moisture contents, saturated hydraulic conductivity and total storage capacities.

\subsubsection{Irrigation}

The map with irrigated areas as developed by FAO, in cooperation with the Center for Environmental Systems Research of the University of Kassel, and the Johann Wolfgang Goethe University Frankfurt am Main (Siebert et al., 2005), is used as input to define irrigation in PCR-GLOBWB. The first version of this map was developed in 1999, but it has been updated continuously. In this study version 4.0.1 is used, which is the most recent version and was released in 2007. Data are available at a spatial resolution of 5 arcminutes (about $10 \times 10 \mathrm{~km}$ ). Irrigated areas in 2030 and 2050 were based on projections published in the study "Agriculture towards 2050" (FAO, 2006).

\subsubsection{Population}

Population data and projections originate from the Center for International Earth Science Network (CIESIN) of Columbia University (CIESIN, 2002). Figure 3 shows that the entire MENA population is projected to grow enormously from 316 million in 2000 to 697 million in 2050. Egypt and Yemen show the largest increases in population.

\subsubsection{Domestic water demand}

Current domestic water requirements are taken from FAO's AQUASTAT database (FAO, 2007). Projections on future domestic demands are not available and were derived therefore using the FAO approach (Bruinsma, 2009). This approach 


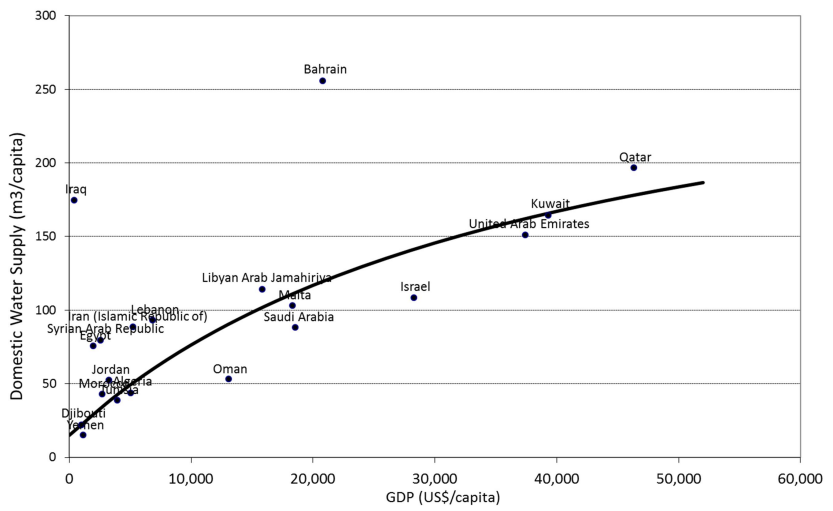

Fig. 4. Relationship between per capita domestic water withdrawals and GDPP.

assumes that there is a correlation between gross domestic product per capita (GDPP) and current water demand per capita. Figure 4 shows that there is generally a clear relationship with Iraq and Bahrain as outliers. Iraq's GDPP has drastically reduced because of the war and political instability while domestic water withdrawals have remained more or less constant. Bahrain has a small population but is a popular tourist destination in the region explaining the relatively high domestic demand. Based on this relationship and future GDPP projections, domestic water requirements up to 2050 are estimated and used in the models.

\subsubsection{Industrial demand}

Data on industrial water withdrawals during the reference period are taken from FAO's AQUASTAT database. Future projections of industrial water requirements are assessed assuming that these depend on gross domestic product (GDP) and GDP per capita (GDPP) according to the following equation (Bruinsma, personal communication and 2009):

$$
\mathrm{IWW}_{\mathrm{yr}}=\mathrm{IWW}_{\mathrm{yr}-1} * \mathrm{GDP}_{\mathrm{yr}} / \mathrm{GDP}_{\mathrm{yr}-1} * \mathrm{GDPP}_{\mathrm{yr}-1} / \mathrm{GDPP}_{\mathrm{yr}}
$$

where $\mathrm{IWW}_{\mathrm{yr}}$ is the industrial water withdrawal for year $\left(\mathrm{km}^{3} \mathrm{yr}^{-1}\right)$. The rationale for this equation is that, if a country produces more GDP, but it does not get richer per person (constant GDPP), industrial water demands will change proportionally with GDP. However, if the country also gets richer per person, it is more inclined to save water. GDP projections are based on the CIESIN data (CIESIN, 2002).

\subsubsection{Current climate}

For the period 2001-2010, climate data were obtained from various public domain sources. Precipitation is based on the TRMM (Tropical Rainfall Measuring Mission) satellite data. These data were made available by the Goddard Earth Sciences Data and Information Services Cen- tre of NASA (National Aeronautics and Space Administration, http://www.nasa.gov/). For temperature and evapotranspiration data, the NCEP/NCAR Reanalysis 1 surface fluxes were taken (http://www.esrl.noaa.gov/psd/data/gridded/data. ncep.reanalysis.surfaceflux.html). These data are used because (i) the temporal resolution is daily, and (ii) it covers the entire current climate from January 2000 through December 2009. Reference evapotranspiration was calculated with the daily average, daily maximum and daily minimum temperature, using the method of Hargreaves (Droogers and Allen, 2002). This is a well-known method for the calculation of reference evapotranspiration, if only average temperature, maximum temperature and minimum temperature are available.

\subsubsection{Climate change}

Climate change data are derived from nine general circulation models (GCMs). These GCM results cannot be used directly for two reasons. First, the resolution of GCMs is on the order of several hundreds of kilometers, which is too coarse for the detailed hydrological assessment required for the study. Second, GCM time series for the past climate show different patterns than observed climate records. Therefore, it was required to downscale GCM output (precipitation, minimum and maximum temperature) using a statistical downscaling approach.

From the various emission scenarios, this study uses the A1B GHG emission scenario. This scenario is chosen because it is widely used and adopted by the IPCC. The A1B scenario is considered as the most likely scenario, because it assumes a world of rapid economic growth, a global population that peaks in mid-century and rapid introduction of new and more efficient technologies. The A1B scenario can be seen as an intermediate between the B1 (low GHG emissions) and A2 (high GHG emissions) scenario (IPCC, 2000).

Shongwe et al. $(2009,2011)$ evaluated the performance of all IPCC GCMs in different regions of Africa by comparing their outputs from 1960-1990 with the observed climate as collected in the CRU TS2.1 dataset (New at al., 2000). The nine best performing GCMs, in terms of simulating historic observed monthly rainfall (Shongwe et al., 2011), were selected to be used in this study. This number of nine models was selected as a trade-off between including sufficient variation and having conceivable calculation times. Selection was based on the performance as described by Shongwe et al. (2011). This has been explained in the manuscript. A statistical downscaling procedure was used in which, for temperature, the difference between observed and GCM-simulated historic values (delta correction) weas used to correct the GCM future projections. For precipitation the same procedure was used but, instead of the absolute difference as correction factor, the fractional difference was used (ratio correction). Downscaling to a spatial resolution of $10 \mathrm{~km}$ was performed using spline interpolation (Mitásová 


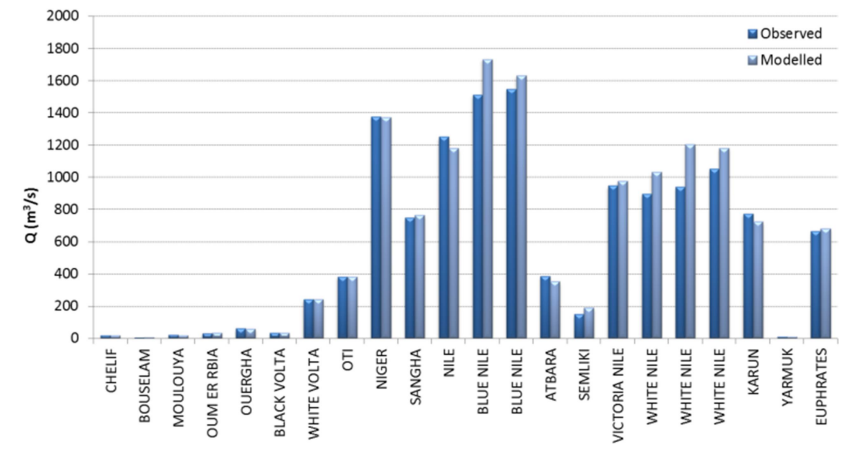

Fig. 5. Long-term average annual observed and simulated flow.

and Mitás, 1993). Details of the downscaling process can be found elsewhere (Immerzeel et al., 2010; Terink et al., 2012).

\section{Results}

\subsection{Model performance}

The original PCR-GLOBWB model has been demonstrated to perform well globally (Van Beek et al., 2011). Although detailed model calibration is not the objective of the current study, the performance of the fine-scaled model as developed for this particular study was assessed separately. For a number of major rivers, the model results were compared to observed data as stored in the Global Runoff Data Centre (GRDC). Given limited data in the study area, also rivers including in the model domain, but not in the MENA region, are included (e.g. Volta). Due to the absence of recent river flow data, the long-term average discharge was used to assess the performance of the model assuming that, if the long-term average hydrology is simulated well, the model can be trusted to assess future changes in water availability. Moreover, it has been proven that relative model accuracy (difference between current situation and scenario) is higher than absolute model accuracy (difference between model output and observations) (Bormann, 2005; Arabi et al., 2007; Droogers et al., 2008).

Figure 5 shows the results of the performance on stream flows. There is a very good match between observed and simulated flow, and therefore it was concluded that the model is able to accurately simulate the average hydrological conditions. In the original model, there was however one exception for the river Nile at the El Ekhsase gauge. The simulated flow in El Ekhsase $\left(2600 \mathrm{~m}^{3} \mathrm{~s}^{-1}\right)$ was substantially higher than the observed river flow $\left(1250 \mathrm{~m}^{3} \mathrm{~s}^{-1}\right)$, while the simulated flows in the Blue and White Nile in Khartoum in Sudan agree well with the observed flows. The fact that Blue Nile, White Nile and Atbara tributaries are simulated well is unique as most model studies have severe problems in accurately simulating these rivers (Mohamed et al., 2005, 2006). The difference in observed and simulated river flow in the
Nile at El Ekhsase can be explained by the following. EL Ekhsase lies on the main Nile in Egypt upstream of the delta, and therefore irrigation abstractions in the delta itself cannot be a reason for this mismatch. The main reason is probably abstractions along the Nile from Khartoum to El Ekhsase in Sudan and Egypt. These abstractions are probably not captured fully in the model given limitations in the irrigated area dataset and the small size (but large in number) abstractions. Moreover, there is a significant water loss from Lake Nasser (Aswan dam) on the order of $10 \mathrm{~km}^{3} \mathrm{yr}^{-1}$ which is also not fully captured in the model. The model was adjusted by including these additional abstractions and evaporation from Lake Nasser.

Obviously, further model improvement might be possible by a more formal calibration process. However, the NashSutcliffe efficiency criterion (NSE), the most commonly used performance indicator to evaluate watershed models, is 0.97 for the final model. Before adjusting the model, as explained in the previous section, NSE was 0.67. The final NSE of 0.97 is considered as very good since NSE values between 0.75 and 1.00 are considered as the highest performance that can be reached in validating models (Moriasi et al., 2007). A more detailed description of the model performance, calibration and validation has been reported to be very good and applicable to the current study (Wada et al., 2011; Sperna Weiland, 2012; Van Beek et al., 2011).

Further calibration of the model was assumed not to be necessary, given the current performance of the model as shown in Fig. 5 and the objectives of the current study. Important to realize is, despite the fact that model performance was based on annual flows, the model runs on a daily base to ensure that hydrological processes are captured correctly. Without such a daily modeling approach, model performance would be probably much lower. Moreover, the model has been demonstrated to capture seasonality very well over various spatial scales and areas (Immerzeel et al., 2009, 2010; Immerzeel and Bierkens, 2009).

\subsection{Water resources}

A typical example of the results of the PCR-GLOBWB model for the current situation is shown in Fig. 6. Renewable water resources (water available for further use) based on the full analysis using the model is a function of precipitation, actual evapotranspiration and the many state variables like soil, groundwater, land cover, slope, climate, drainage, amongst others. The actual evapotranspiration is, besides the precipitation, the biggest term of the water balance. Figure 7 presents future water availability for the entire MENA region based on PCR-GLOBWB for the period 2010-2050. It is clear that the total internal renewable water resources and the recharge show a significant decline. This is the combined effect of the changes in precipitation and evapotranspiration. It should be noted that, although groundwater declines are severe, the contribution of groundwater compared to surface 

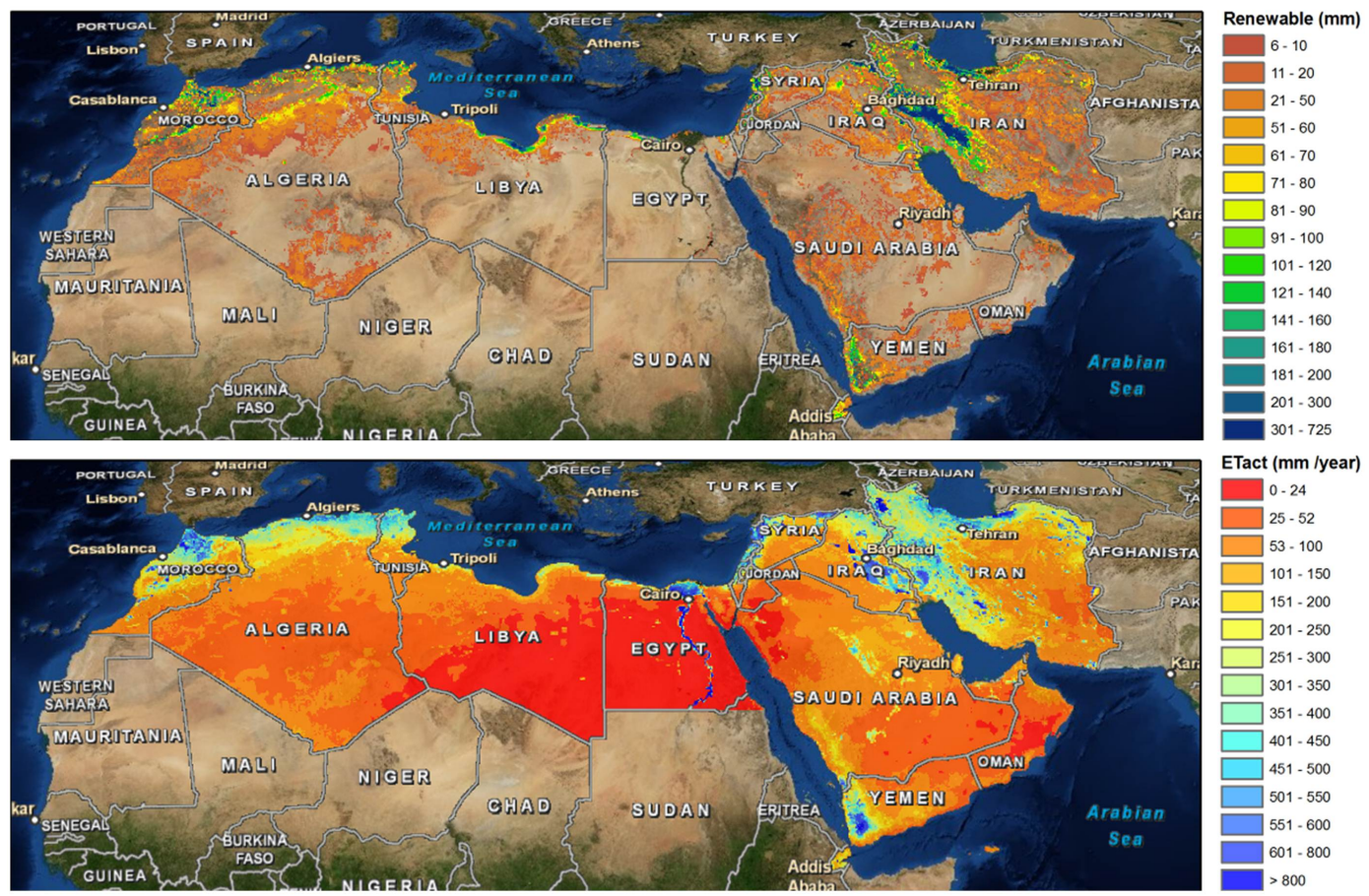

ETact (mm /year)

0.24

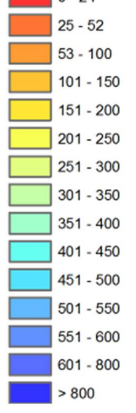

Fig. 6. Internal renewable water resources and actual evapotranspiration based on PCR-GLOBWB for the period 2000-2009.

water is relatively small for the entire MENA region. Obviously, for some countries this decline in groundwater is one of the main threats to sustainable water resources. The total external renewable water resources show a very small increase for the entire region. This is mainly attributed to the fact that the majority of the external water resources are provided by the Nile and an increase in precipitation is projected by most GCMs in Eastern Africa where most Nile water is generated. However, increased abstractions by urban and industry might be expected in this region, which is not included in our analysis. However, additional abstractions for irrigations, the major consumer, are included in our analysis. The combined effect is that the total renewable water resources show a negative trend aggregated over the entire MENA region. The average total MENA renewable water resources from 2000 to 2009 equals about $250 \mathrm{~km}^{3}$, and this is projected to decline by $0.6 \mathrm{~km}^{3}$ per year to 2050 . The Fig. 7 shows also that there is considerable variation between the different GCMs and that the results should be interpreted with care. Nonetheless, it is safe to conclude that an overall decrease in water resources is likely to occur in the future.

There is great variation between the different MENA countries in the hydrological response to climate change. Groundwater recharge shows a very sharp decrease in almost all countries. This decrease is generally much stronger than the projected decrease in precipitation, and this can be explained by the increase in evapotranspiration and the nonlinearity of hydrological processes. In relative terms some of the GCC countries (Oman, U.A. Emirates, Saudi Ara- bia) show the largest decline. However, in some of the wetter countries, the decline is also very considerable (Morocco $-38 \%$, Iraq $-34 \%$, Iran $-22 \%$ ) and this might lead to severe problems in the future. The internal and external renewable water resources also show negative trends throughout the region with the exception of Egypt, Djibouti and Syria. The largest decreases are observed in Jordan $(-98 \%)$, Oman $(-46 \%)$, Saudi Arabia $(-36 \%)$ and Morocco $(-33 \%)$. In Syria the internal renewable water resources show an increase but the total renewable water resources show a decrease, because the external inflow of the Euphrates into Syria is projected to decrease by $17 \%$. More details on the water resources assessment can be found elsewhere (Immerzeel et al., 2010, 2011, 2012)

\subsection{Water supply and demand}

The overall water supply and demand analysis, as based on the MENA-WOF model for the entire MENA region, is presented in Table 1 . Total demand will increase by $132 \mathrm{~km}^{3}$ per year, while total water shortage will grow by $157 \mathrm{~km}^{3}$ per year for the average climate change projection. This enormous increase in shortage is the collective impact of the increase in demand by $50 \%$ combined with the decrease in supply by $12 \%$. What is interesting is that the changes in supply are mainly attributed to a decrease in surface water availability, while groundwater supply shows a relatively small decrease compared to total supply. 

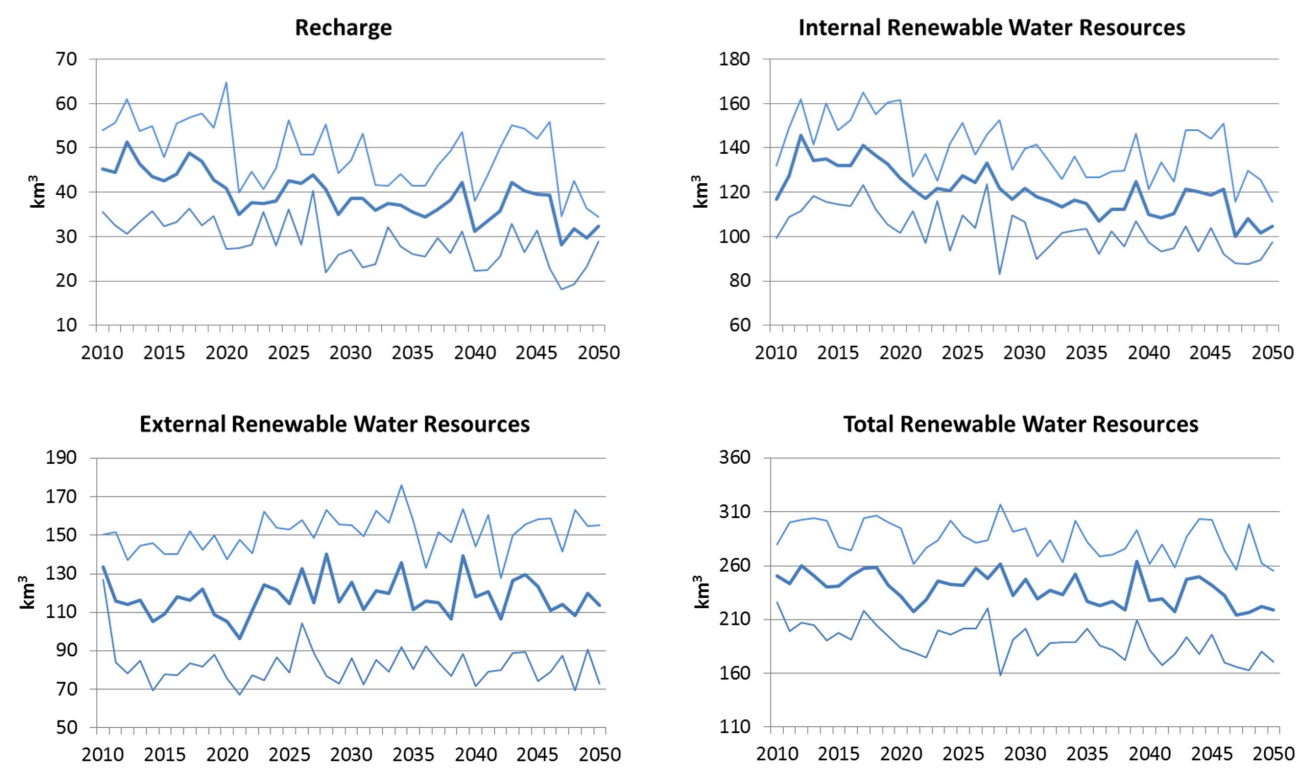

Fig. 7. Total gross recharge, internal, external and total renewable water resources from 2010 to 2050 . The thick line is the average of the nine GCMs, and the thin lines show the second wettest and second driest GCM.

Table 1. Annual water supply and demand for the MENA region for current (2001-2010) and future (2041-2050) time frames. Future projections include ignoring climate change (No_CC), and scenarios for average, dry and wet projections. All numbers in $\mathrm{km}^{3}$ per year.

\begin{tabular}{lrrrrr}
\hline & Current & No_CC & Avg_CC & Dry_CC & Wet_CC \\
\hline DEMAND & 261 & 380 & 393 & 412 & 374 \\
Irrigation & 213 & 251 & 265 & 283 & 246 \\
Urban & 28 & 88 & 88 & 88 & 88 \\
Industry & 20 & 41 & 41 & 41 & 41 \\
UNMET & & & & & \\
DEMAND & 42 & 164 & 199 & 283 & 85 \\
Irrigation & 36 & 109 & 136 & 199 & 53 \\
Urban & 4 & 37 & 43 & 56 & 20 \\
Industry & 3 & 18 & 20 & 27 & 11 \\
SUPPLY & 219 & 215 & 192 & 129 & 290 \\
Surface water & 171 & 168 & 151 & 97 & 237 \\
Groundwater & 48 & 47 & 41 & 31 & 53 \\
\hline
\end{tabular}

The analyses are also undertaken for the driest and the wettest climate projections (Table 1). Logically, only the irrigation demand differs between these different climate projections, while no impact on urban and industrial demands is seen in our analysis. Obviously, in reality some increase in demand might occur by some additional water need for cooling requirements and/or bathing. However, these amounts are considered to be minor compared to other impacts. In terms of supply, these climate projections have a rather big impact. What is interesting is that, even under the most positive projection, water shortage is increasing from $42 \mathrm{~km}^{3}$ per year currently to $85 \mathrm{~km}^{3}$ per year in 2050 , despite the increase in water resources availability. The increase in demand by socio-economic factors outbalances the increase in additional water resources availability as projected for the wet climate projection.

The progression of water demand, supply and shortage up to 2050 is presented in Fig. 8. These figures show the demand for irrigation, domestic and industry, the water supply (split between groundwater and surface water) and total water shortage for the entire MENA region. These results are obtained by taking the sum of the 22 countries in the MENA region on an annual base. It is important to realize however that these results are based on daily calculations by the hydrological model (and monthly for the water demand-supply model) to ensure that variations within a year are properly taken into account. The figures show the year-to-year variation too, which is especially noticeable in surface water availability.

From these results it can be concluded that the current water shortage in the MENA region is around $42 \mathrm{~km}^{3}$ per year (2000-2009). The annual variation is known as well and ranges between $24 \mathrm{~km}^{3}$ (2004) and $64 \mathrm{~km}^{3}$ (2008). This is already a substantial unmet demand, and a clear reflection of the conditions in the MENA region where water shortage is already occurring in most of the countries.

Changes in water demand (Table 2) and water shortage (Table 3) are also presented per country. Changes in demand do not clearly show specific country or regional trends, but are a result of the complex interactions between population growth, economic development and changes in irrigation water demand. Overall, countries with high population growth and countries with a relatively low current water demand will experience substantial growths in water demand in the future. An increase in water shortages is projected for all countries 

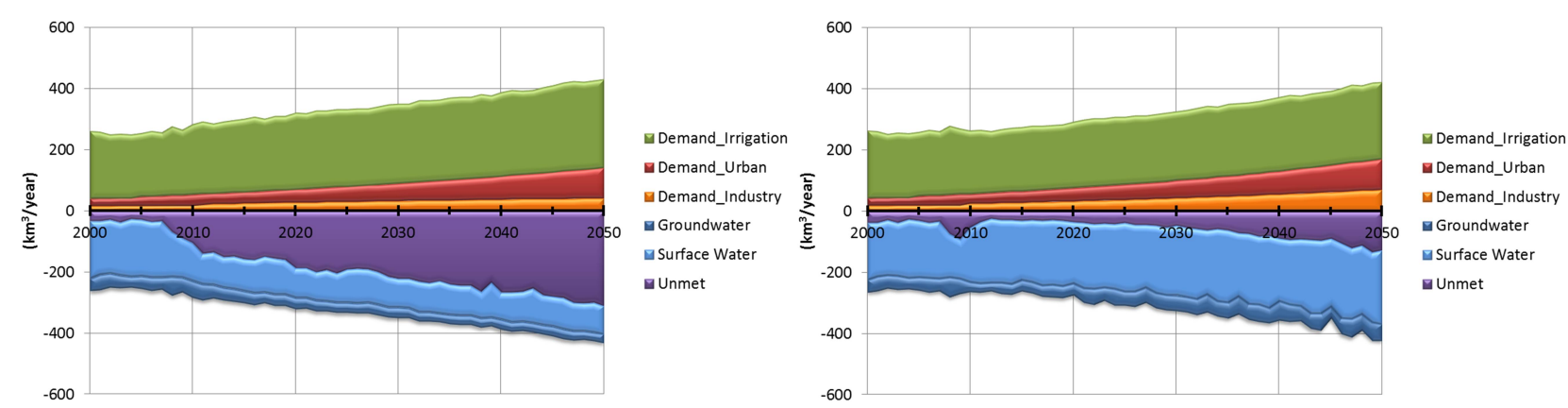

Fig. 8. Water demand and supply MENA for the climate scenario AVG (top) and DRY (middle) and WET (bottom).

Table 2. Annual water demand for the 22 countries for the current (2001-2010) and future (2041-2050) periods. Future projections include ignoring climate change (No_CC), and scenarios for average, dry and wet projections. All numbers in million $\mathrm{m}^{3} \mathrm{yr}^{-1}$.

\begin{tabular}{lrrrrr}
\hline & Current & No_CC & Avg_CC & Dry_CC & Wet_CC \\
\hline Algeria & 6356 & 11912 & 12336 & 12818 & 11878 \\
Bahrain & 226 & 390 & 391 & 392 & 390 \\
Djibouti & 28 & 84 & 84 & 85 & 82 \\
Egypt & 55837 & 85281 & 87681 & 90381 & 85235 \\
Gaza Strip & 119 & 308 & 313 & 319 & 307 \\
Iran & 74537 & 93111 & 97107 & 103461 & 90949 \\
Iraq & 50160 & 81622 & 83803 & 87415 & 80336 \\
Israel & 2526 & 4089 & 4212 & 4371 & 4047 \\
Jordan & 1113 & 2219 & 2276 & 2349 & 2207 \\
Kuwait & 508 & 1214 & 1216 & 1219 & 1212 \\
Lebanon & 1202 & 1804 & 1869 & 1994 & 1746 \\
Libya & 4125 & 5763 & 5982 & 6241 & 5727 \\
Malta & 45 & 75 & 75 & 76 & 75 \\
Morocco & 15739 & 22624 & 24223 & 25939 & 22443 \\
Oman & 763 & 1681 & 1709 & 1733 & 1668 \\
Qatar & 325 & 385 & 395 & 405 & 382 \\
Saudi Arabia & 20439 & 25945 & 26633 & 27424 & 25857 \\
Syria & 15311 & 20495 & 21337 & 22525 & 20028 \\
Tunisia & 2472 & 4150 & 4452 & 4808 & 4000 \\
U.A. Emirates & 3370 & 3277 & 3389 & 3491 & 3212 \\
West Bank & 341 & 689 & 709 & 741 & 679 \\
Yemen & 5560 & 12610 & 12889 & 13556 & 12002 \\
\hline
\end{tabular}

with the exception of Djibouti (Table 3). Countries with relatively high agricultural water consumption are expected to face a substantial increase in water shortage.

\subsection{Climate change versus other changes}

The results discussed above reflect the combination of projections in socio-economic development as well as average and extreme climate change projections. An interesting scientific, but also policy-related, question is what the contribution of only climate change would be. To this end, the entire modeling framework has been set up assuming climate in 2050 would remain similar to current climate conditions, but socio-economic changes would occur as expected. Table 1 shows for the entire MENA region (under column "No_CC")
Table 3. Same as Table 2, but here water shortage. All numbers in million $\mathrm{m}^{3} \mathrm{yr}^{-1}$.

\begin{tabular}{lrrrrr}
\hline & Current & No_CC & Avg_CC & Dry_CC & Wet_CC \\
\hline Algeria & 0 & 1082 & 3947 & 574 & 0 \\
Bahrain & 195 & 379 & 383 & 389 & 378 \\
Djibouti & 0 & 0 & 0 & 0 & 0 \\
Egypt & 2858 & 31332 & 31648 & 61867 & 0 \\
Gaza Strip & 98 & 296 & 301 & 311 & 293 \\
Iran & 8988 & 27882 & 39939 & 65716 & 5262 \\
Iraq & 11001 & 48748 & 54860 & 68529 & 38181 \\
Israel & 1660 & 3213 & 3418 & 3818 & 2946 \\
Jordan & 853 & 1914 & 2088 & 2286 & 1808 \\
Kuwait & 0 & 835 & 801 & 977 & 510 \\
Lebanon & 141 & 732 & 891 & 1259 & 496 \\
Libya & 0 & 3193 & 3650 & 3931 & 73 \\
Malta & 0 & 14 & 36 & 51 & 16 \\
Morocco & 2092 & 7369 & 15414 & 19554 & 8219 \\
Oman & 0 & 1145 & 1143 & 1343 & 458 \\
Qatar & 83 & 174 & 246 & 314 & 122 \\
Saudi Arabia & 9467 & 20045 & 20208 & 22717 & 17136 \\
Syria & 323 & 4135 & 7111 & 12086 & 437 \\
Tunisia & 0 & 0 & 837 & 2726 & 0 \\
U.A. Emirates & 3036 & 3112 & 3189 & 3403 & 2851 \\
West Bank & 210 & 580 & 624 & 696 & 539 \\
Yemen & 1120 & 8285 & 8449 & 10471 & 4838 \\
\hline
\end{tabular}

the impact on water demand, unmet demand and water supply. Results indicate that only $10 \%$ of the change in water demand can be attributed to climate change, while the remaining $90 \%$ is a result from socio-economic changes (for the average climate projection). Considering the dry climate projection, $21 \%$ can be attributed to climate change. Interesting to note is that, under the wet projections, water demand will slightly decrease compared to the no climate change case due to more precipitation.

The water shortage owing to only climate change is especially interesting. Table 1 indicates that this water shortage is more strongly related to socio-economic factors. Considering the average climate projection, $22 \%$ of the water shortage can be attributed to climate change and $78 \%$ to changes in socio-economic factors. Taking the dry climate projection as reference, $49 \%$ of water shortage is caused by climate change and $51 \%$ by socio-economic factors. Water shortage 
Table 4. Contribution of socio-economic changes and climate changes on total water demand in 2050.

\begin{tabular}{lrrrr}
\hline & $\begin{array}{c}\text { Socio- } \\
\text { Economics (\%) }\end{array}$ & Mean (\%) & Dry (\%) & Wet (\%) \\
\hline Algeria & 93 & 7 & 14 & -1 \\
Bahrain & 99 & 1 & 1 & 0 \\
Djibouti & 99 & 1 & 3 & -3 \\
Egypt & 92 & 8 & 15 & 0 \\
Gaza Strip & 97 & 3 & 5 & -1 \\
Iran & 82 & 18 & 36 & -13 \\
Iraq & 94 & 6 & 16 & -4 \\
Israel & 93 & 7 & 15 & -3 \\
Jordan & 95 & 5 & 11 & -1 \\
Kuwait & 100 & 0 & 1 & 0 \\
Lebanon & 90 & 10 & 24 & -11 \\
Libya & 88 & 12 & 23 & -2 \\
Malta & 100 & 0 & 4 & 0 \\
Morocco & 81 & 19 & 32 & -3 \\
Oman & 97 & 3 & 5 & -1 \\
Qatar & 85 & 15 & 25 & -5 \\
Saudi Arabia & 89 & 11 & 21 & -2 \\
Syria & 86 & 14 & 28 & -10 \\
Tunisia & 85 & 15 & 28 & -10 \\
Emirates & 100 & 0 & 0 & 0 \\
West Bank & 95 & 5 & 13 & -3 \\
Yemen & 96 & 4 & 12 & -9 \\
MENA & 90 & 10 & 21 & -5 \\
\hline & & & &
\end{tabular}

is smaller compared to the no climate projection under the wet climate projection.

Table 4 presents results for the individual countries in MENA. For all countries socio-economic development plays a much larger role compared to climate change in terms of water demand. There are however differences amongst countries resulting from the complex interplay between different hydrological, socio-economic and country-specific characteristics. For countries that are already heavily waterstressed (Kuwait, Malta, Emirates), additional stress by climate change is relatively low compared to socio-economic development. Countries where a considerable amount of water is allocated to irrigation (e.g. Iran, Morocco) are obviously susceptible to changes in climate. What is interesting, in this respect is, for example, the difference between Bahrain (no irrigation) and Oman and Saudi Arabia (some irrigation development).

\section{Conclusions}

The study presented here is unique in terms of combining different data, models and tools to come to an overall water outlook over a large area. The strength of the approach is a consistent methodology over all countries so that intercomparison is not affected by differences in approach. A drawback of the presented approach is that calibration/validation is less detailed than what would be possible if smaller areas and/or a more mono-disciplinary approach would have been followed.

Uncertainty in the results presented originates mainly from (i) models, (ii) data, and (iii) projections. The hydrological model used here is based on the well-established PCRaster framework and the PCR-GLOBWB implementation. This model is described extensively in literature and has been validated over a range of different conditions. The water supply-demand model is built in WEAP, again a very wellestablished and tested modeling framework. The data used to feed these models originate from reliable and published sources (climate, land cover) and less-developed datasets (soils, reservoir operations). Finally, data on climate projections are by definition uncertain. This is partly overcome by using a selection of the nine best performing GCMs out of a total of 21 . These nine were all used in the hydrological model, and results from these analyses were used to feed the average, the wettest and the driest projection into the supply-demand model. The projections of population growth and especially of economic development are uncertain, but based on rigorous analysis by CIESIN. At the same time, questions on the desired required accuracy of projections are being raised given uncertainties on policy that will be implemented over the coming decades (Dessai et al., 2009).

The hydrological model PCR-GLOBWB is developed as a "general-purpose" model. In the MENA region, hyper-arid areas can be found where rain falls in the form of intense and short storms causing flash floods. In general, these short storms may not be well-captured by daily time step models such as the PCR-GLOBWB as used in this study. However, total rainfall of these storms compared to overall rainfall over the larger area considered in this study might be relatively low. This is also demonstrated by the fact that the hydrological model is, over larger areas, able to mimic observed runoffs quite well as demonstrated in this paper. However, a detailed analysis over a subset of the entire study area might be undertaken, but is beyond the scope of the current study.

Results from the study show clearly that, for the region under study, climate change is only a small factor in projected water shortage over the coming decades. However, given the already enormous water shortage in the region, this climate component should be taking into consideration in planning processes. The presented non-linearity in hydrological processes multiplies this even further: demand is increasing by about $50 \%$, unmet demand by $370 \%$. In other words - the amount of unmet demand currently is relatively small compared to the future.

Comparing the results to other studies is complex given the unique nature of the approach presented here. The " 2030 Water Resources Group" (Addams et al., 2009) concluded that, for the MENA region, the increase in demand would be $99 \mathrm{~km}^{3}$ in 2030. The current study indicates that the increase in demand would be $74 \mathrm{~km}^{3}$ in 2030 . It is however not completely clear what the " 2030 WRG" study means by "increase in demand". The study sometimes refers to this 
"increase in demand" when "water shortage" is meant, which are obviously different terms. The current study makes a clear distinction between total demand in $2030\left(335 \mathrm{~km}^{3}\right)$, increase in demand in $2030\left(74 \mathrm{~km}^{3}\right)$, total unmet demand in $2030\left(134 \mathrm{~km}^{3}\right)$, and increase in unmet demand in 2030 $\left(91 \mathrm{~km}^{3}\right)$.

A study by Wit and Stankiewicz (2006) estimated that climate change will lead to a decrease in perennial drainage which will significantly affect surface water access across $25 \%$ of Africa by the end of this century. Their focus was very much on the nonlinear response of drainage to rainfall, and climate change will therefore most seriously affect regions in the intermediate, unstable climate regime. Our study presented here took a more integrated approach instead of focusing on drainage only.

The study "Economics of Adaptation to Climate Change (EACC)" (World Bank, 2010) concludes that developing countries have to spend $0.12 \%$ of their GDP in 2050 to overcome the negative impact of climate change. Although costs in 2030 will be lower compared to 2050, in terms of GDP the number is higher $(0.2 \%)$ as the economies are projected to grow substantially between 2030 and 2050. Actual amounts of changes in water demand and/or water shortages are not mentioned in the EACC study, while this is one of the main outcomes of the current study.

A comprehensive study on the options desalination might offer to overcome water shortage in the MENA basin includes a water shortage analysis as well (Trieb and MullerSteinhagen, 2008). The study projects an increase in total water demand from $270 \mathrm{~km}^{3}$ in 2000 to $460 \mathrm{~km}^{3}$ in 2050 and that the demand-supply gap will increase from $50 \mathrm{~km}^{3}$ in 2000 to $150 \mathrm{~km}^{3}$ in 2050 for the region. The study was not based on any hydrological modeling but on FAO statistics. Moreover, the study did not include climate change which might explain that their projected water shortages are lower than the results of the current study.

Further research work on these topics can go in two directions. First, a more detailed analysis can be undertaken if smaller areas, e.g. country level, would be studied using the same methodology (e.g. Droogers, 2009; Giertz et al., 2006). The second line of research to be undertaken is an analysis on potential adaptation strategies and costs of these adaptations using the developed framework (e.g. Agrawala and Aalst, 2008; Droogers and Aerts, 2005).

Acknowledgement. We gratefully acknowledge comments and suggestions that we have received from several anonymous reviewers and from the editor. The development of this paper has benefited substantially from their comments.

Edited by: S. Uhlenbrook

\section{References}

Abu-Zeid, K., Wagdy, A., Elbadawy, O., and Abdel-Meguid A.: State of the Water Report in the Arab Region, CEDARE and the Arab Water Council, Cairo, Egypt, 2004.

Abu-Zeid, M. and El-Shibini, F. Z.: Egypt's High Aswan Dam, Water Resources Development, 13, 209-217, 1997.

Addams, L., Boccaletti, G., Kerlin, M., and Stuchtey, M.: Charting Our Water Future: Economic frameworks to inform decisionmaking, Water, Vol. 21, 2030 Water Resources Group, available at: http://www.mckinsey.com/App_Media/Reports/Water/ Charting_Our_Water_Future_Full_Report_001.pdf, 2009.

Agrawala, S. and van Aalst, M.: Adapting Development Cooperation to Adapt Climate Change, Climate Policy, 8, 183-193, 2008.

Allam, M. N.: Water Resources and Future Challenges in the Arab World, First Regional Conference on "Perspectives of Arab Water Cooperation: Challenges, Constraints and Opportunities", Cairo, Egypt, 2002.

Arabi, M., Govindaraju, R. S., and Hantush, M. M.: A probabilistic approach for analysis of uncertainty in the evaluation of watershed management practices, J. Hydraul. 333, 459-471, 2007.

Bergström, S.: The HBV Model, in: Computer models of watershed hydrology, edited by: Singh, V. P., Colorado, Water Resources Publications, 443-476, 1995.

Bormann, H.: Evaluation of hydrological models for scenario analyses: signal-to-noise-ratio between scenario effects and model uncertainty, Adv. Geosci., 5, 43-48, doi:10.5194/adgeo-5-43-2005, 2005.

Bruinsma, J.: The resource outlook to 2050, FAO Expert Meeting on How to Feed the World in 2050, available at: ftp://ftp. fao.org/docrep/fao/012/ak971e/ak971e00.pdf (last access: $1 \mathrm{Au}-$ gust 2012), 2009.

CEDARE: Water Conflicts and Conflict Management Mechanisms in the Middle East and North Africa Region, Centre for Environment and Development for the Arab Region and Europe (CEDARE), 2006.

Center for International Earth Science Information Network (CIESIN): Country-level GDP and Downscaled Projections based on the A1, A2, B1, and B2 Marker Scenarios, 1990-2100, [digital version]. Palisades, NY: CIESIN, Columbia University, available at: http://sedac.ciesin.columbia.edu/mva/downscaling/ ciesin.html (last access: 1 February 2012), 2002.

Conway, D.: The development of a grid-based hydrological model of the Blue Nile and the sensitivity of Nile river discharge to climate change, University of East Anglia, 1993.

Dessai, S., Hulme, M., Lempert, R., and Pielke, R.: Do We Need Better Predictions to Adapt to a Changing Climate?, Eos, 90, 111-112, 2009

Droogers, P.: Climate Change and Hydropower, Impact and Adaptation Costs: Case Study Kenya, FutureWater Report, 85, 2009.

Droogers, P. and Aerts, J.: Adaptation strategies to climate change and climate variability: a comparative study between seven contrasting river basins, Phys. Chem. Earth, 30, 339-346, 2005.

Droogers, P. and Allen, R. G.: Estimating reference evapotranspiration under inaccurate data conditions, Irrig. Drain. Syst., 16, 33-45, 2002.

Droogers, P. and Perry, C.: Scenario Based Water Resources Model to Support Policy Making, Report World Bank and FutureWater, 79, 47 pp., 2008. 
Droogers, P., Van Loon, A., and Immerzeel, W. W.: Quantifying the impact of model inaccuracy in climate change impact assessment studies using an agro-hydrological model, Hydrol. Earth Syst. Sci., 12, 669-678, doi:10.5194/hess-12-669-2008, 2008.

Elshamy, M. E.: Assessing the Hydrological Performance of the Nile Forecast System in Long Term Simulations, Nile Water Science \& Engineering Magazine, 1, 22-36, 2008.

Elshamy, M. E., Seierstad, I. A., and Sorteberg, A.: Impacts of climate change on Blue Nile flows using bias-corrected GCM scenarios, Hydrol. Earth Syst. Sci., 13, 551-565, doi:10.5194/hess13-551-2009, 2009.

Falkenmark, M. and Lannerstad, M.: Consumptive water use to feed humanity - curing a blind spot, Hydrol. Earth Syst. Sci., 9, 1528, doi:10.5194/hess-9-15-2005, 2005.

FAO: Digital Soil map of the World, Food and Agriculture Organization of the United Nations (FAO), Rome, Italy, 1998.

FAO: Agriculture Towards 2030/2050: Prospects for food, nutrition, agriculture and major commodity groups: interim report, Rome, Italy, 2006.

FAO: Review of global agricultural water use per country, Irrigation water use per country in the year 2000, AQUASTAT, 2000, available at: http://www.fao.org/AG/agL/aglw/aquastat/ water_use/index5.stm (last access: 1 February 2012), 2007.

FAO: State of Food Insecurity in the World 2009, Food and Agriculture Organization of the United Nations, 2010.

Giertz, S., Diekkrüger, B., and Steup, G.: Physically-based modelling of hydrological processes in a tropical headwater catchment (West Africa) - process representation and multicriteria validation, Hydrol. Earth Syst. Sci., 10, 829-847, doi:10.5194/hess-10-829-2006, 2006.

Hanasaki, N., Kanae, S., Oki, T., Masuda, K., Motoya, K., Shirakawa, N., Shen, Y., and Tanaka, K.: An integrated model for the assessment of global water resources - Part 2: Applications and assessments, Hydrol. Earth Syst. Sci., 12, 1027-1037, doi:10.5194/hess-12-1027-2008, 2008.

Immerzeel, W. W. and Bierkens, M. F. P.: Seasonal prediction of monsoon rainfall in three Asian river basins: the importance of snow cover on the Tibetan Plateau", Int. J. Climatol., 30, 18351842, doi:10.1002/joc.2033, 2009.

Immerzeel, W. W., Droogers, P., de Jong, S. M., and Bierkens, M. F. P.: Large-scale monitoring of snow cover and runoff simulation in Himalayan river basins using remote sensing, Remote Sens. Environ., 113, 40-49, 2009.

Immerzeel, W. W., Beek, L. P. H., and Bierkens, M. F. P.: Climate Change Will Affect the Asian Water Towers, Science, 328, 1382$1385,2010$.

Immerzeel, W. W., Droogers, P., Terink, W., Hoogeveen, J., Hellegers, P., Bierkens, M., and Van Beek, R.: Middle-East and Northern Africa Water Outlook, Report FutureWater, 98, 2011.

Immerzeel, W. W., Droogers, P., Terink, W., van Beek, R., and Bierkens, M. F. P.: Future water resources availability in the Middle East and Northern Africa, Water Resources Management, submitted, 2012.

IPCC: Emissions Scenarios. A Special Report of IPCC Working Group III, Intergovernmental Panel on Climate Change, Bern, Switzerland, 2000.

IPCC: Climate Change 2007: Synthesis Report, Intergovernmental Panel on Climate Change, Bern, Switzerland, 2007.
Legesse, D., Vallet-Coulomb, C., and Gasse, F.: Hydrological response of a catchment to climate and land use changes in Tropical Africa: case study South Central Ethiopia, J. Hydrol., 275, 67-85, 2003.

Meigh, J. R., McKenzie, A. A., and Sene, K. J.: A Grid-Based Approach to Water Scarcity Estimates for Eastern and Southern Africa, Water Resour. Manage., 13, 85-115, 1999.

Mitásová, H. and Mitás, L.: Interpolation by Regularized Spline with Tension: I. Theory and Implementation, Math. Geol., 25, 641-655, 1993.

Mohamed, Y. A., van den Hurk, B. J. J. M., Savenije, H. H. G., and Bastiaanssen, W. G. M.: Hydroclimatology of the Nile: results from a regional climate model, Hydrol. Earth Syst. Sci., 9, 263278, doi:10.5194/hess-9-263-2005, 2005.

Mohamed, Y. A., Savenije, H. H. G., Bastiaanssen, W. G. M., and van den Hurk, B. J .J. M.: New lessons on the Sudd hydrology learned from remote sensing and climate modeling, Hydrol. Earth Syst. Sci., 10, 507-518, doi:10.5194/hess-10-507-2006, 2006.

Molden, D. (Ed.): Water for Food, Water for Life: a Comprehensive Assessment of Water Management in Agriculture. Earthscan, London, UK; and International Water Management Institute (IWMI), Colombo, Sri Lanka, 2007.

Moriasi, D. N., Arnold, J. G., Van Liew, M. W. and Bingner, R. L.: Model evaluation guidelines for systematic quantification of accuracy in watershed simulations, T. ASABE, 50, 885-900, 2007.

New, M., Lister, D., Hulme, M., and Makin, I.: A high-resolution data set of surface climate over global land areas, Clim. Res., 21, $1-25,2002$.

Rosegrant, M. W., Ringler, C., and Zhu, T.: Water for Agriculture: Maintaining Food Security under Growing Scarcity, Annu. Rev. Environ. Resour., 34, 205-22, 2009.

SEI: WEAP Water Evaluation and Planning system, Stockholm Environment Institute, USA, 2005.

Shongwe, M., van Oldenborgh, G., van den Hurk, B., de Boer, B., Coelho, C., and van Aalst, M.: Projected changes in mean and extreme precipitation in Africa under global warming. Part I: Southern Africa, J. Climate, 22, 3819-3837, 2009.

Shongwe, M., van Oldenborgh, G., van den Hurk, B., and van Aalst, M:. Projected changes in mean and extreme precipitation in Africa under global warming, Part II: East Africa, J. Climate, 24, 3718-3733, doi:http://dx.doi.org/10.1175/2010JCLI2883.1, 2011.

Siebert, S., Döll, P., Hoogeveen, J., Faures, J.-M., Frenken, K., and Feick, S.: Development and validation of the global map of irrigation areas, Hydrol. Earth Syst. Sci., 9, 535-547, doi:10.5194/hess-9-535-2005, 2005.

Sperna Weiland, F. C.: Hydrological impacts of climate change Interpretation of uncertainties introduced by global models of climate and hydrology, Utrecht University, available at: http://igitur-archive.library.uu.nl/dissertations/ 2011-1130-200336/sperna_weiland.pdf, 2011.

Terink, W., Immerzeel, W. W., and Droogers, P.: Climate change in the Middle East and North Africa for 2050: a country-level approach, Climatic Change, in preperation, 2012.

Trieb, F. and Muller-Steinhagen, H.: Concentrating solar power for seawater desalination in the Middle East and North Africa, Desalination, 220, 165-168, 2008. 
USGS: Global Land Cover Characterization (GLCC), United States Geological Survey (USGS), available at: http://eros.usgs.gov/ (last access: 1 August 2012), 2008.

USGS: HYDRO1k Elevation Derivative Database. United States Geological Survey (USGS), available at: http://eros.usgs.gov/ (last access: 1 August 2012), 2012.

Van Beek, L. P. H. and Bierkens, M. F. P.: The Global Hydrological Model PCR-GLOBWB: Conceptualization, Parameterization and Verification, Report Department of Physical Geography, Utrecht University, Utrecht, The Netherlands, available at: http: //vanbeek.geo.uu.nl/suppinfo/vanbeekbierkens2009.pdf, 2009.

Van Beek, L. P. H., Wada, Y., and Bierkens, M. F. P.: Global monthly water stress: 1 . Water balance and water availability, Water Resour. Res., 47, W07517, doi:10.1029/2010WR009791, 2011.

Wada, Y., Van Beek, L. P. H., Viviroli, D., Dürr, H.H., Weingartner, R., and Bierkens, M. F. P.:. Global monthly water stress: 2 . Water demand and severity of water stress", Water Resour. Res., 47, 117, 2011.

Wesseling, C. G., Karssenberg, D., Van Deursen, W. P. A., and Burrough, P. A.: Integrating dynamic environmental models in GIS: the development of a Dynamic Modelling language, Transactions in GIS, 1, 40-48, 1996.
Wit, de M. and Stankiewicz, J.: Changes in surface water supply across Africa with predicted climate change, Science, 311, 19171921, 2006.

World Bank: Middle East and North Africa Data Profile, Based on World Development Indicators database, Washington DC, USA, August, 2005.

World Bank: Making the Most of Scarcity Accountability for Better Water Management Results in the Middle East and North Africa, The MENA Development report, 2007.

World Bank: The Economics of Adaptation to Climate Change, Synthesis Report, 2010.

WRI: World Resources Institute (WRI) in collaboration with United Nations Development Programme, United Nations Environment Programme, and World Bank, World Resources 2005: The Wealth of the Poor-Managing Ecosystems to Fight Poverty, Washington, DC, WRI, 2005.

Yates, D., Sieber, J., Purkey, D., and Huber-Lee, A.: WEAP21 - A demand-, priority-, and preference-driven water planning model Part 1: Model characteristics, Water Int., 30, 487-500, 2005. 